\title{
Hubungan Kecukupan Asupan Energi dan Status Gizi dengan Tingkat Kelelahan Kerja Pekerja Bagian Produksi (Studi di PT. Multi Aneka Pangan Nusantara Surabaya) \\ Relationship between Sufficient Intake of Energy, Nutritional Status and the Level of Labor Exhaustion among Production Workers (Study at PT Multi Aneka Pangan Nusantara Surabaya)
}

\author{
Arini Rahmatika Sari ${ }^{1}$, Lailatul Muniroh ${ }^{2}$
}

\begin{abstract}
ABSTRAK
Pendahuluan: Kelelahan kerja menjadi keadaan umum yang dialami hampir semua tenaga kerja, namun jika hal ini terjadi secara terus menerus dapat mempengaruhi kondisi kesehatan pekerja. Kelelahan kerja dapat dipengaruhi oleh berbagai faktor, beberapa diantaranya yaitu asupan energi dan status gizi pekerja.

Tujuan: Tujuan penelitian ini adalah menganalisis hubungan kecukupan asupan energi dan status gizi dengan tingkat kelelahan kerja pekerja.

Metode: Penelitian ini merupakan penelitian observasional analitik menggunakan desain cross sectional dengan sampel sebesar 33 pekerja dari 48 pekerja bagian produksi cocoa powder PT. Multi Aneka Pangan Nusantara Surabaya yang dipilih menggunakan metode simple random sampling. Pengumpulan data menggunakan food recall $2 \times 24$ hours untuk asupan energi, pengukuran berat badan dan tinggi badan untuk status gizi, serta kuesioner Industrial Fatigue Research Committee (IFRC) untuk tingkat kelelahan kerja. Analisis data menggunakan uji statistik ranks spearman.

Hasil: Sebagian pekerja besar responden berusia $<25$ tahun $(42,4 \%)$, kecukupan asupan energi yang tergolong kurang $(66,7 \%)$, status gizi normal $(54,5 \%)$, dan tingkat kelelahan kerja yang tergolong sedang $(63,6 \%)$. Terdapat hubungan antara kecukupan asupan energi $(p=0,001)$ dan status gizi $(p=0,018)$ dengan tingkat kelelahan kerja pekerja.

Kesimpulan:. Semakin kurang asupan energi dan semakin tinggi IMT maka akan semakin tinggi tingkat kelelahan kerja pada pekerja.
\end{abstract}

Kata Kunci: asupan energi, status gizi, kelelahan kerja, pekerja

\begin{abstract}
Introduction: Work Fatigue is the common condition experienced by most worker but if this condition occured continously, it will affect of the worker's health condition. Work fatigue can be affected by several factors, some of which are energy intake and nutritional status.

Objective: The aim of this research was to analyze the correlation between the adequacy of energy intake and nutritional status with the level of work fatigue.

Methods: This study was an analytic observational, used cross sectional study with 33 sample from 48 workers of cocoa powder production PT. Multi Aneka Pangan Nusantara Surabaya selected by simple random sampling. Data were collected by food recall $2 X 24$ hours for energy intake, measuring
\end{abstract}


weight and height for nutritional stastus and Industrial Fatigue Research Committee (IFRC) questionnaire for the level of fatigue. Data were analyzed by ranks spearman correlation test.

Results: Most of workers were $<25$ years old (42.4\%), the adequacy of energy intake were deficit (66.7\%), the nutritional status were normal (54.5\%), and the work fatigue were moderate (63.6\%). The result of this research showed that there were corellation between the adequacy of energy intake ( $p$-value $=0.001)$ and nutritional status ( $p$-value $=0.018)$ with the level of work fatigue.

Conclussion: In conclusion, lower energy intake and high BMI would increase the level of fatigue.

Keywords : energy intake, nutritional status, work fatigue, worker

*Koresponden:

Rahmatikatika31@gmail.com

${ }^{1}$ Prodi S-1 Ilmu Gizi FKM Universitas Airlangga Surabaya, Indonesia

\section{PENDAHULUAN}

Kesehatan yang prima pada pekerja dapat menjadi penentu tingginya produktivitas kerja namun ketika kesehatan pekerja terganggu kemampuan berfikir maupun melakukan pekerjaan fisik dapat menurun. Salah satu contoh gangguan kesehatan yang dapat dialami oleh pekerja ialah kelelahan kerja ${ }^{1}$. Kelelahan merupakan keadaan umum yang dialami kebanyakan tenaga kerja setelah melakukan pekerjaan. Apabila keadaan tersebut terjadi dalam waktu yang berkepanjangan, maka dapat mempengaruhi kondisi kesehatan tenaga kerja dan tentunya mempengaruhi produktivitas kerja ${ }^{2}$. Pekerja industri merupakan tenaga kerja yang paling rentan mengalami kelelahan kerja. Penelitian sebelumnya menyebutkan bahwa terdapat 43,3\% pekerja yang terdapat pada industri keripik mengalami kelelahan kerja ${ }^{3}$.

Kelelahan ditandai dengan turunnya performa baik mental maupun fisik yang disebabkan oleh pekerjaan yang berlangsung lama, kurangnya jam tidur dan jam istirahat yang tidak beraturan ${ }^{4}$. Kelelahan menjadi gambaran dari terjadinya ketidaknormalan keadaan fisik dengan mental ${ }^{1}$. Kelelahan yang terjadi pada pekerja tidak dapat didefinisikan secara signifikan karena hal tersebut hanya dapat dirasakan oleh pekerja ${ }^{5}$. Kelelahan fisik dan psikologis menjadi dua bentuk dasar kelelahan kerja ${ }^{6}$. Kelelahan kerja ditandai dengan adanya penurunan performa kerja seperti keletihan, kelesuan, bingung, frustasi, sakit kepala, nyeri sendi dan otot ${ }^{7}$. Kelelahan kerja dapat menjadi penyebab dari terjadinya cedera, kecelakaan kerja hingga kematian pada tempat kerja ${ }^{6}$. Data International Labour Organization (ILO) tahun 2013 menunjukkan terdapat kurang lebih satu pekerja meninggal dan 160 pekerja mengalami gangguan kesehatan setiap 15 detik karena kecelakaan kerja yang disebabkan oleh kelelahan kerja ${ }^{8}$.

Kelelahan kerja dapat dipengaruhi oleh banyak faktor seperti usia, jenis kelamin, lingkungan kerja, intensitas kerja, faktor psikologi, asupan makanan, penyakit hingga status kesehatan ${ }^{9}$. Asupan makanan dapat mempengaruhi ketersediaan energi seseorang 10. Kebutuhan Energi bagi pekerja adalah kebutuhan energi atau kebutuhan gizi normalnya ditambah dengan kebutuhan energi atau kalori untuk melaksanakan aktivitas dalam pekerjaannya ${ }^{1}$. Asupan energi dan zat gizi yang baik secara kualitas maupun kuantitas dapat menentukan daya kesehatan dan produktivitas pekerja ${ }^{11,1}$. Asupan energi yang tidak sesuai dengan kebutuhan dapat menjadi penyebab dari keadaan gizi buruk. Hal tersebut dapat menurunkan derajat kesehatan seseorang, terutama dalam memudahkan terjadinya kelelahan kerja ${ }^{1}$. Penelitian sebelumnya menyebutkan bahwa $77,8 \%$ pekerja yang mengalami kelelahan kerja memiliki asupan energi yang kurang ${ }^{12}$.

Faktor yang berhubungan dengan kesehatan seperti status gizi pekerja, memiliki potensi yang tinggi dalam menyebabkan kelelahan kerja ${ }^{13}$. Status gizi, yang merupakan kebutuhan gizi, seharusnya untuk dipenuhi oleh setiap tenaga kerja karena dapat 
berpengaruh untuk meningkatkan derajat kesehatan dan mengoptimalkan daya kerja pekerja. Hal tersebut masih belum banyak dipahami oleh pengusaha maupun pekerja di berbagai perusahaan ${ }^{1}$. Status gizi yang kurang maupun berlebih dapat menjadi penyebab turunnya derajat kesehatan pekerja. Pekerja dalam kondisi status gizi tersebut walaupun dalam tingkat paling ringan masih tetap mempengaruhi penurunan performa dan konsentrasi kerja, sehingga kemungkinan terjadi kelelahan kerja dapat semakin meningkat ${ }^{11}$. Hal tersebut sejalan dengan penelitian yang telah dilakukan sebelumnya menyebutkan bahwa 63,3\% kejadian kelelahan kerja terjadi pada pekerja yang memiliki status gizi yang buruk, sehingga status gizi sangat berpengaruh terhadap kejadian kelelahan kerja ${ }^{14}$.

PT. Multi Aneka Pangan Nusantara merupakan perusahaan yang memproduksi beberapa bahan makanan yang berhubungan dengan cokelat, salah satunya yaitu cocoa powder. Pada penelitian pendahuluan yang dilakukan, didapatkan bahwa sebanyak 48 pekerja dalam produksi cocoa powder memiliki beban kerja yang sama dalam kelompok kerja yang berbeda yaitu persiapan, pencampuran, pemilihan, penggorengan, penghalusan, serta pengemasan. Pekerja bekerja selama 9 jam kerja dengan waktu istirahat setengah hingga satu jam diantara waktu tersebut. Sebanyak $31,25 \%$ dari total populasi pekerja memiliki status gizi dalam kategori malnutrisi. Perusahaan belum dilakukan dengan food recall $2 \times 24$ hours untuk mengetahui jumlah energi yang dikonsumsi pekerja dalam waktu 24 jam. Asupan energi pekerja dikategorikan menjadi kurang jika $<77 \%$ AKE dan cukup jika $\geq 77 \%$ $\mathrm{AKE}^{15}$. Pengukuran tersebut dilakukan dalam waktu 2 hari dalam waktu yang tidak berurutan Status gizi diketahui melalui perhitungan nilai IMT yang didapat dari pengukuran berat badan dan tinggi badan. Pengukuran berat badan menggunakan timbangan digital merk krisbow dengan tingkat kepekaan $\pm 0,05 \mathrm{~kg}$ dan tinggi badan menggunakan microtoise merk GEA medical dengan tingkat kepekaan 0,1 cm. Hasil pengukuran tersebut dihitung menggunakan memberikan fasilitas penyelenggaraan makanan dan hanya memberikan fasilitas air pada galon selama bekerja. Waktu istirahat yang singkat dan jarangnya penjual makanan disekitar perusahaan menyebabkan pekerja jarang mengkonsumsi makanan, terutama pada saat sarapan. Hal tersebut kemungkinan besar dalam mempengaruhi asupan energi dan status gizi pekerja yang berpotensi tinggi menyebabkan kelelahan kerja.

Tujuan penelitian ini adalah menganalisis antara kecukupan asupan energi dan status gizi dengan tingkat kelelahan kerja yang terjadi pada pekerja bagian produksi cocoa powder PT. Multi Aneka Pangan Nusantara Surabaya.

\section{METODE}

Jenis penelitian ini yaitu observasional analitik dengan desain cross sectional. Penelitian dilakukan di PT. Multi Aneka Pangan Nusantara Surabaya dengan waktu pengambilan data yaitu bulan Juli-Agustus 2017. Populasi penelitian ialah semua pekerja bagian produksi cocoa powder sebanyak 48 pekerja. Pengambilan sampel sebanyak 33 pekerja dilakukan dengan cara simple random sampling.

Penelitian ini telah lulus uji etik dengan nomor 461-KEPK dari komite etik penelitian kesehatan Fakultas Kesehatan Masyarakat Universitas Airlangga. Pengumpulan data jenis kelamin dan usia dilakukan dengan wawancara menggunakan kuesioner. Pengukuran asupan energi rumus IMT yaitu pembagian berat badan dalam satuan kilogram (Kg) dengan kuadrat tinggi badan dalam satuan meter $\left(\mathrm{m}^{2}\right)$. Hasil perhitungan dikategorikan menjadi jika $<18,5$, normal jika 18,5-25,0, overweight jika 25,127,0 , dan obesitas jika $>27,0$. Pengukuran tingkat kelelahan kerja diukur menggunakan kuesioner Industrial Fatigue Research Committee (IFRC) yang berisi 30 pertanyaan dan dinilai menggunakan skala Likert dengan skor 1-4 sehingga total skor dapat dikategorikan sebagai tingkat kelelahan rendah jika 30-52, sedang jika 53-75, tinggi jika 76-98 dan sangat tinggi jika 99-120. Analisis data menggunakan uji korelasi ranks spearman untuk menganalisis hubungan 
antara variabel kecukupan asupan energi dan status gizi dengan tingkat kelelahan kerja yang terjadi pada pekerja.

\section{HASIL DAN PEMBAHASAN}

Dalam penelitian ini, karakteristik responden yang diteliti yaitu jenis kelamin, usia, kecukupan asupan energi, status gizi dan kelelahan kerja. Jenis kelamin dan usia dapat berhubungan dengan kekuatan fisik atau performa seseorang dalam beraktivitas. Kecukupan asupan energi didapatkan dari hasil jumlah energi konsumsi makanan dan minuman menggunakan food recall $2 \times 24$ hours yang dibandingkan dengan angka kecukupan energi (AKE) untuk pekerja sesuai dengan jenis kelamin dan usia. Distribusi karakteristik responden dalam penelitian ini dapat dilihat pada Tabel 1.

Tabel 1. Distribusi Responden Menurut Karakteristik Responden Pekerja Bagian Produksi PT. Multi Aneka Pangan Nusantara Surabaya Tahun 2017

\begin{tabular}{lcc}
\hline \multicolumn{1}{c}{ Variabel } & Jumlah & Persentase \\
\cline { 2 - 3 } & $\mathbf{n}$ & $\%$ \\
\hline $\begin{array}{l}\text { Jenis kelamin } \\
\text { Laki-laki }\end{array}$ & 33 & 100 \\
$\quad$ Perempuan & 0 & 0 \\
Usia & & \\
$\quad$ <25 Tahun & 14 & 42,4 \\
$\quad$ 25-30 Tahun & 9 & 27,3 \\
$\quad>30$ Tahun & 10 & 30,3 \\
Kecukupan Asupan & & \\
Energi & 22 & 66,7 \\
$\quad$ Kurang (<77\% AKE) & 11 & 33,3 \\
$\quad$ Cukup ( $\geq 77 \%$ AKE) & & \\
Status Gizi & & \\
$\quad$ Underweight & 5 & 15,2 \\
$\quad$ Normal & 18 & 54,5 \\
$\quad$ Overweight & 4 & 12,1 \\
$\quad$ Obesitas & 6 & 18,2 \\
Kelelahan Kerja & & \\
$\quad$ Ringan & 3 & 9,1 \\
$\quad$ Sedang & 21 & 63,6 \\
$\quad$ Tinggi & 9 & 27,3 \\
\hline
\end{tabular}

Hasil penelitian yang disajikan pada Tabel 1 menunjukkan bahwa semua (100\%) pekerja pada bagian produksi cocoa powder berjenis kelamin laki-laki. Pada dasarnya, pekerja dengan jenis kelamin perempuan cenderung memiliki kekuatan fisik atau otot yang lebih lemah dibandingkan dengan kekuatan otot atau fisik yang dimiliki oleh lakilaki. Kekuatan otot yang dimiliki perempuan setidaknya $2 / 3$ dari kekuatan otot yang dimiliki laki-laki ${ }^{16}$. Hal tersebut dapat menjadi salah satu alasan perusahaan untuk mempekerjakan pekerja laki-laki untuk bagian produksi, karena pada bagian ini dibutuhkan cukup banyak energi.

Usia dapat memberikan pengaruh terhadap kekuatan fisik seorang pekerja. Kekuatan fisik atau kekuatan otot semakin menurun sejalan dengan bertambahnya usia seseorang. Usia juga mempengaruhi emosi pekerja yang berkaitan dengan kematangan mental seseorang dan pengalaman kerja, menjadi faktor penyebab terjadinya kelelahan kerja ${ }^{5}$. Hasil penelitian pada Tabel 1 menunjukkan bahwa sebagian besar $(42,4 \%)$ pekerja memiliki usia <25 tahun, sedangkan distribusi usia responden berkisar antara 20 hingga 46 tahun, dimana usia tersebut merupakan usia produktif seseorang untuk melakukan pekerjaan ${ }^{17}$. Dalam rentang usia tersebut seseorang dapat mengalami peningkatan berat badan hingga peningkatkan jaringan adiposa serta terjadi penurunan massa otot yang menyebabkan turunnya performa seseorang dalam beraktivitas. Di sisi lain, seseorang pada usia 25-30 tahun memiliki kemampuan otot maupun fisik yang optimal dan dapat secara langsung mengalami penurunan setelah usia tersebut ${ }^{18}$. Hal tersebut menyebabkan turunnya performa seseorang, sehingga memudahkan seseorang merasakan kelelahan.

Hasil penelitian yang disajikan pada Tabel 1 menunjukkan bahwa sebagian besar $(66,7 \%)$ energi yang dikonsumsi pekerja masih tergolong kurang $(<77 \%)$ dari angka kecukupan energi (AKE) untuk pekerja yang disesuaikan dengan jenis aktivitas, usia dan juga jenis kelamin. Hal ini menunjukkan bahwa pekerja belum memenuhi kebutuhannya untuk melakukan segala kegiatan umum dan juga pekerjaannya. Konsumsi energi seorang pekerja dapat menentukan kondisi kesehatan dan kemampuan fisik atau daya kerjanya, sehingga energi yang keluar dalam melakukan segala 
aktivitasnya sangat bergantung pada konsumsi energi pekerja ${ }^{19}$. Asupan energi yang tidak sesuai dengan kebutuhan pekerja untuk melakukan aktivitasnya menyebabkan daya kerja menurun, sehingga dapat timbul berbagai masalah seperti kelelahan kerja hingga menurunnya produktivitas pekerja ${ }^{20}$. Rendahnya konsumsi pekerja dapat dipicu oleh fasilitas penyelenggaraan makanan yang belum disediakan oleh pihak perusahaan dan hanya diberikan dalam bentuk uang menjadi salah satu penyebab pemenuhan energi dan zat gizi lainnya tidak sesuai dengan kebutuhan pekerja.

Berdasarkan Tabel 1 diketahui bahwa sebagian besar pekerja (54,5\%) memiliki status gizi yang normal. Hasil wawancara yang dilakukan pada responden menunjukkan bahwa pekerja menjadi jarang mengkonsumsi makanan ketika pekerja berada di hari kerja atau tidak berada di rumah, sedangkan ketika di rumah pekerja lebih memiliki asupan makanan yang lebih teratur dan lebih beragam. Hal tersebut memungkinkan menjadi penyebab lebih banyak pekerja dengan gizi normal namun sebagian besar pekerja memiliki kecukupan asupan energi yang kurang. Status gizi berhubungan dengan kelelahan kerja karena secara langsung berpengaruh terhadap performa kerja seseorang. Status gizi berhubungan dengan konsumsi seorang pekerja dan aktivitas yang dilakukan pekerja. Status gizi yang buruk atau tidak optimal menyebabkan terganggunya aktivitas pekerja dalam melakukan setiap pekerjaannya karena adanya penuruhanan daya kerja serta terjadinya perlambatan gerak $^{5,1}$.

Penilaian kelelahan kerja dengan menggunakan kuesioner IFRC menunjukkan hasil kelelahan kerja yang terjadi pada pekerja sebagian besar $(63,6 \%)$ merupakan tingkat kelelahan kerja sedang (53-75) yaitu sebanyak 21 pekerja. Hasil tersebut menunjukkan bahwa pekerja mengalami kelelahan kerja yang membutuhkan perbaikan dikemudian hari. Kelelahan kerja disebabkan karena faktor pekerjaan dan faktor di luar pekerjaan atau dari individu pekerja sendiri ${ }^{1,5}$. Beberapa faktor yang berasal dari individu pekerja sendiri yang berhubungan dengan kelelahan kerja yaitu seperti asupan energi dan status gizi pekerja. Hal tersebut sejalan dengan penelitian terdahulu yang menyebutkan bahwa terdapat hubungan antara status gizi dan asupan energi dengan kelahan kerja yang terjadi pada karyawan perusahaan tahu baxo ${ }^{21}$.

Pada Tabel 2. hasil tabulasi silang antara kecukupan asupan energi dan kelelahan kerja menunjukkan bahwa tingkat kelelahan kerja tinggi hanya dialami oleh pekerja dengan asupan energi dalam kategori kurang. Berdasarkan hasil uji korelasi menggunakan ranks spearman, didapatkan nilai $p=0,001 \quad(p<0,05)$ yang menunjukkan terdapat korelasi negatif yang cukup kuat ( $r=-$ 0,548 ) antara kecukupan asupan energi dan tingkat kelelahan kerja. Hasil tersebut menunjukkan sebagai semakin kurang tingkat kecukupan asupan energi maka semakin tinggi tingkat kelelahan kerja. Hal ini sejalan dengan penelitian yang dilakukan pada pekerja di PT. Perkebunan Nusantara I pabrik kelapa sawit Pulau Tiga menyebutkan bahwa asupan energi yang kurang atau tidak terpenuhi maka dapat semakin meningkatkan kelelahan kerja ${ }^{20}$.

Asupan energi menjadi faktor utama yang dibutuhkan oleh pekerja untuk melakukan kegiatan umum dan juga untuk melaksanakan kerja. Hal tersebut dapat sangat mempengaruhi kemampuan seseorang dalam melakukan aktivitasnya. Dalam keadaan berkontraksi, pembuluh darah yang terdapat pada serat otot akan terjepit, sehingga peredaran darah dapat terhambat. Oksigen yang dibutuhkan tubuh menjadi berkurang karena darah yang berfungsi untuk membawa nutrien dan oksigen tidak dapat mengalir dengan lancar ${ }^{1}$. Asupan energi dari konsumsi pekerja memasok glikogen dan oksigen yang digunakan otot untuk berkontraksi. Glikogen menjadi pemasok utama energi dalam yang digunakan untuk kontraksi otot, ketika glukosa tubuh sudah mulai mengalami penurunan. Glikogen diubah menjadi glukosa dan secara langsung mengalami glikolisis sehingga menghasilkan asam piruvat dan membentuk adenosine triphosphate (ATP) yang digunakan untuk kontraksi otot. Dalam pembentukan ini, jika dalam pemecahan asam piruvat tidak ada 
suplai oksigen, maka terbentuk menjadi asam laktat. Asam laktat yang terbentuk secara terus menerus, maka dapat menyebabkan terjadinya penumpukan dalam otot. Sehingga ketika asupan energi kurang, pemasukan glikogen yang digunakan untuk kontraksi otot menjadi sangat kurang. Hal tersebut menyebabkan regenerasi atau produksi ATP tidak dapat seimbang dengan penggunaan ATP ditambah dengan kurangnya oksigen yang menyebabkan penumpukan asam laktat sehingga memudahkan pekerja mengalami kelelahan kerja ${ }^{22,23}$. Tabel 3 menunjukkan bahwa tingkat kelelahan kerja tinggi lebih banyak dialami oleh pekerja dengan status gizi obesitas. Hasil uji korelasi menggunakan ranks spearman, didapatkan nilai $p=0,018 \quad(p<0,05)$ yang menunjukkan korelasi positif yang cukup kuat $(r=0,409)$ antara status gizi dengan tingkat kelelahan kerja pekerja. Hal tersebut diartikan sebagai status gizi yang semakin berlebih dapat semakin meningkatkan tingkat kelelahan kerja yang terjadi pada pekerja.

Tabel 2. Distribusi Kecukupan Asupan Energi Menurut Tingkat Kelelahan Kerja Pekerja Bagian Produksi PT. Multi Aneka Pangan Nusantara Surabaya Tahun 2017

\begin{tabular}{|c|c|c|c|c|c|c|c|c|}
\hline \multirow{3}{*}{$\begin{array}{c}\text { Kecukupan asupan } \\
\text { energi }\end{array}$} & \multicolumn{6}{|c|}{ Tingkat kelelahan kerja } & \multirow{2}{*}{\multicolumn{2}{|c|}{ Total }} \\
\hline & \multicolumn{2}{|c|}{ Ringan } & \multicolumn{2}{|c|}{ Sedang } & \multicolumn{2}{|c|}{ tinggi } & & \\
\hline & $n$ & $\%$ & $\mathbf{n}$ & $\%$ & $\mathbf{n}$ & $\%$ & $\mathbf{n}$ & $\%$ \\
\hline Kurang & 0 & 0,0 & 13 & 59,1 & 9 & 40,9 & 22 & 100 \\
\hline Cukup & 3 & 27,3 & 8 & 72,7 & 0 & 0,0 & 11 & 100 \\
\hline
\end{tabular}

Tabel 3. Distribusi Status Gizi Menurut Tingkat Kelelahan Kerja Pada Pekerja Bagian Produksi PT. Multi Aneka Pangan Nusantara Surabaya Tahun 2017

\begin{tabular}{lcccccccc}
\hline \multirow{2}{*}{ Status Gizi } & \multicolumn{9}{c}{ Tingkat kelelahan kerja } & \multicolumn{2}{c}{ Total } \\
\cline { 2 - 7 } & \multicolumn{2}{c}{ Ringan } & \multicolumn{2}{c}{ Sedang } & \multicolumn{2}{c}{ tinggi } & \multicolumn{2}{c}{} \\
\cline { 2 - 8 } & $\mathbf{n}$ & $\mathbf{\%}$ & $\mathbf{n}$ & $\mathbf{\%}$ & $\mathbf{n}$ & $\mathbf{\%}$ & $\mathbf{n}$ & $\mathbf{\%}$ \\
\hline Underweight & 0 & 0,0 & 4 & 80 & 1 & 20 & 5 & 100 \\
Normal & 3 & 16,7 & 13 & 72,2 & 2 & 11,1 & 18 & 100 \\
Overweight & 0 & 0 & 3 & 75 & 1 & 25 & 4 & 100 \\
Obesity & 0 & 0 & 1 & 16,7 & 5 & 83,3 & 6 & 100 \\
\hline
\end{tabular}

$\rho$-value $=0,018, \mathrm{r}=0,409$

Hasil penelitian ini sejalan dengan penelitian sebelumnya menyebutkan bahwa status gizi lebih memiliki risiko lebih tinggi untuk mengalami kelelahan kerja ${ }^{24}$. Gizi yang baik berdampak pada derajat kesehatan, ketahanan tubuh hingga produktivitas pekerja ${ }^{1}$. Penumpukan massa lemak yang terjadi dalam tubuh dikarenakan tingginya konsumsi makanan tinggi karbohidrat dan lemak. Ketika konsumsi lebih tinggi dari yang digunakan maka dapat menyebabkan tempat penyimpanan tidak mampu lagi menampungnya, sehingga zat-zat gizi tersebut disimpan pada tempat yang tidak seharusnya atau dapat menjadi tumpukan lemak pada beberapa organ tubuh seperti organ vital tubuh. Hal tersebut tentunya dapat menurunkan fungsi normal organ-organ tersebut ${ }^{19}$. Hal tersebut dapat menyebabkan penumpukan asam laktat sebagai hasil samping dari metabolisme energi, dimana asam piruvat yang dipecah tanpa bantuan oksigen dapat menyumbang asam laktat pada darah dan otot. Penumpukan asam laktat tersebut akan mempengaruhi rasa sakit dan lelah pekerja ${ }^{5}$.

\section{KESIMPULAN}

Terdapat hubungan antara kecukupan asupan energi dan status gizi dengan kelelahan kerja pekerja. Kecukupan asupan energi yang semakin kurang atau semakin defisit akan meningkat kan tingkat kelelahan kerja.

\section{ACKNOWLEDGEMENT}

Terima kasih dan penghargaan diberikan penulis kepada seluruh staf pengajar program studi ilmu gizi Universitas Airlangga atas bimbingannya. 


\section{REFERENSI}

1. Suma'mur. Higiene Perusahaan dan Kesehatan Kerja (Hiperkes). jakarta: sagung seto; 2009.

2. WorkSafe Victoria. Fatigue Prevention in the Workplace. WorkSafe Victoria [Internet] 2008;(1). Available from: https://www.worksafe.vic.gov.au/_data/asse ts/pdf_file/0008/9197/vwa_fatigue_handboo k.pdf

3. Ahmad S, Amanatun A. Beban Kerja Dengan Kelelahan Pada Pekerja Industri Keripik Melinjo di Desa Benda Indramayu. kesehatan masyarakat 2015;1(3).

4. Trade Unions Center. Fatigue An introduction for union health and safety representatives. 2016;(July):1-5.

5. Maurits LSK. Selintas Tentang Kelelahan Kerja. Yogyakarta: Penerbit Amara Books; 2010.

6. Yassierli, Oktoviona D, Ulin I. Hubungan Antara Indikator Pengukuran Kelelahan Kerja Dan Metode Cepat Penilaian Risiko Ergonomi. 2016;1(1).

7. Hockey R. The psychology of fatigue: Work, effort and control. [Internet]. The psychology of fatigue: Work, effort and control. cambridge: cambridge university press; 2013. 51-78 p. Available from: http://ovidsp.ovid.com/ovidweb.cgi?T=JS\&PA $\mathrm{GE}=$ reference \&D$=$ psyc10\&NEWS $=\mathrm{N} \& A N=2013$ $-19412-000$

8. Kemenkes RI. 1 Orang Pekerja di Dunia Meninggal Setiap 15 Detik Karena Kecelakaan Kerja [Internet]. jakarta; 2014. Available from: http://www.depkes.go.id/article/view/201411 030005/1-orang-pekerja-di-dunia-meninggalsetiap-15-detik-karena-kecelakaan-kerja.html

9. Lusiana D, Zahroh S, Baju S, Kesehatan F, Universitas $M$, Kesehatan $F$, Universitas $M$. Penyebab Kelelahan Kerja pada Pekerja Mebel Factors Caused Fatigue among Furniture Workers. 2013;

10. Almatsier S. Prinsip Dasar IImu Gizi. jakarta: PT. Gramedia Pustaka; 2005.

11. Kemenkes RI. Pedoman Pemenuhan Kecukupan Gizi Pekerja Selama Bekerja. jakarta: Direktorat Bina Kesehatan Kerja Kementerian Kesehatan Republik Indonesia; 2010.
12. Umiyarni PD, Ulfah N. Pengaruh konsumsi energi dan protein terhadap kelelahan pada pekerja wanita di industri bulu mata palsu PT Hyup Sung Purbalingga. InSeminar Nasional Kesehatan Purwokerto; 2012. p. 1-11.

13. Shearer J, Graham TE, Skinner TL. Nutraergonomics : influence of nutrition on physical employment standards and the health of workers 1. 2016;174(June):165-74.

14. Ismayenti L. Effect Of Heat Stress and Nutrition Status on Worker Fatigueat Traditional Music Gamelan Industry. InInternational Conference on Applied Science and Health surakarta: ICASH; 2017. p. 136-41.

15. Gibson RS. Principles of Nutrition. USA: Oxford University Press; 2005.

16. Tarwaka, Bakri S, Sudiajeng L. Ergonomi untuk Kesehatan dan Keselamatan Kerja dan Produktivitas. surakarta: UNIBA Press; 2004.

17. Kemenkes RI. Panduan Akupresur Mandiri Bagi Pekerja di Tempat Kerja. Jakarta: Kementerian Kesehatan Republik Indonesia; 2015.

18. Brown JE. Nutrution through the Life Cycle. Fluoride. 2011. 296-309 p.

19. Sediaoetama AD. Ilmu Gizi. 1st ed. Jakarta: Dian Rakyat; 2012.

20. Tasmi D, Dkk. hubungan Status Gizi dan Asupan Energi Dengan Kelelahan Kerja Oada Pekerja di PT. Perkebunan Nusantara 1 Pabrik Kelapa Sawit Pulau Tiga Tahun 2015. 2015;2015.

21. Langgar DP, Setyawati VA. Hubungan Asupan Gizi dan Status Gizi dengan Kelelahan Kerja pada Karyawan Perusahaan Tahu Baxo Bu Pudji di Ungaran Tahun 2014. Visikes UDINUS 2014;13(2):127-35.

22. A. J, Driskell, Wolinsky I. Nutritional Concerns in Reactin, Exercise, and Sport. New York: CRC Press; 2009.

23. Kam P, Power I. Principles of Physiology for the Anaesthetist. Second. New York: CRC Press; 2012.

24. Perwitasari D, Tualeka AR. Faktor yang Berhubungan Dengan Kelelahan Kerja Pada Perawat Di RSUD DR . Mohamad Soewandhie Surabaya. The Journal of Occupational Safety, Health and Environtment 2014;1:15-23. 